\title{
Comparative Analysis of Heat Pump System with IHX Using R1234yf and R134a
}

\author{
Róbert Sánta ${ }^{\text {* }}$ \\ ${ }^{1}$ Department of Mechanical Engineering, University of Dunaújváros, H-2400 Dunaújváros, Táncsics Mihály u. 1/a, Hungary \\ * Corresponding author, e-mail: santar@uniduna.hu
}

Received: 20 April 2021, Accepted: 07 May 2021, Published online: 13 September 2021

\begin{abstract}
This research presents an energy performance analysis of the heat pump system with internal heat exchanger (IHX). The mathematical model of the heat pump outlined in this paper has been created by the author, it is steady-state with lumped parameters. The experimental validation of the model has been carried out using R1234yf and R134a as refrigerant. The aim of this work is to compare the energy performance in a wide range of operating conditions of a monitored heat pump system using both refrigerants. Finally, the heating capacity for R1234yf was lower from $0.63 \%$ to $7.54 \%$ compared with R134a, while the compressor power was similar from $0.12 \%$ to $3.51 \%$. The COP values of R1234yf were lower than those obtained of R134a, ranging from $1.39 \%$ to $4.22 \%$.
\end{abstract}

\section{Keywords}

heat pump, IHX, R1234yf, R134a, COP

\section{Introduction}

Safely accessible and affordable energy are vital factors in the future path of Hungary, assuring social security and high performance of modern industries. The most efficient and successful method to solve this issue in the short run is by reducing energy consumption and improving energy efficiency. A key element in increasing energy efficiency is implementing improvements in building energy. Currently an estimated $40 \%$ of overall energy in Hungary is used within buildings, and two-thirds of this amount is used up in the form of heating and cooling [1].

The implementation of heat engines is one of the most efficient heating-cooling technologies as well as a key factor in lowering the global $\mathrm{CO}_{2}$ emission and air pollution.

In the past few years much, scientific attention has been paid to the use of vapor compression cycles with and without internal heat exchangers [2-5]. Research works have dealt with the comparison of cooling capacity amounts, power consumption of the system and COP parameters when operating at various evaporation and condenser temperatures implementing R1234yf and R1234ze(E) as possible alternatives for R134a [6-9].

Navarro-Esbrí et al. [10] experimentally showed that for a vapor compression plant, the replacement of R-134a for R-1234yf reduces the cooling capacity and the COP by $6 \%$ and $13 \%$, respectively, but with the inclusion of IHX, these reductions become $2 \%$ and $6 \%$, respectively. Devecioğlu and Oruç [11] compared the energy performance in a refrigeration system using R-1234yf and $\mathrm{R}-1234 \mathrm{ze}(\mathrm{E})$ with the energy performance of R-134a using an IHX. Their results showed that, despite a reduced refrigeration capacity with $\mathrm{R} 1234 \mathrm{ze}(\mathrm{E})$, the energy consumption was also reduced, and comparing it with R-1234yf, the COP of R1234ze(E) was higher. They also concluded that, with IHX, the COP of the system for R-1234ze(E) was $3 \%$ higher than that obtained for R134a without IHX.

Yang et al. [12] compared R513A and R-134a in a domestic refrigerator without IHX and reported that R-513A offered a higher refrigeration capacity in comparison with R134a. They also evaluated the energy consumption and found that using R513A, the energy was reduced by $3.5 \%$ in comparison with R-134a. Mota-Babiloni et al. [13] presented an exergy analysis of an experimental setup which operated with R134a and the alternative HFO/HFC mixture R513A. The evaporating temperature ranged between $-15^{\circ} \mathrm{C}$ and $5{ }^{\circ} \mathrm{C}$, while the condensing temperature was set at $30{ }^{\circ} \mathrm{C}$ and $35^{\circ} \mathrm{C}$. Pérez-García et. al [14] presented a study on the first and second law of thermodynamics using experimental data from a medium capacity 
refrigeration system using R-450A, R-513A and R-134a as working fluids.

Mota-Babiloni et al. [15] performed an exergy study in an experimental installation with R-513A without IHX, demonstrating that the global exergy efficiency of R-513A was slightly higher than the one obtained with R-134a under the same operation conditions, though R-513A presented a higher amount of exergy destruction. MotaBabiloni et al. [16] performed an energy comparison in an experimental installation where they found that the refrigeration capacity was higher for R-134a in comparison with R-450A with and without IHX. Wantha [17] outlined the experimental and theoretical evaluation of heat transfer characteristics of a tube-in-tube internal heat exchanger for R1234yf and R134a refrigerants. They investigated the relationship between the COP and the overall heat transfer coefficient, the influence on the length and effectiveness of the heat exchanger, annular space, and pressure drops under operating conditions between $-6.4{ }^{\circ} \mathrm{C}$ and $+6.4{ }^{\circ} \mathrm{C}$ evaporation and $46^{\circ} \mathrm{C}$ condensation temperature. It was revealed that the exergetic COP increased with the effectiveness of the internal heat exchanger, i.e., $4.4 \%$ for R1234yf and $1.35 \%$ for R134a. Belman-Flores et. al [18] presented an energy and exergy analysis of a domestic refrigeration system using R1234yf as a drop-in replacement for R134a. Mendoza-Miranda et. al [19] in their comparative evaluation of the compressor predictions showed a reduction in the cooling capacity obtained with R1234yf, R450A and $\mathrm{R} 1234 \mathrm{ze}(\mathrm{E})$, in comparison with R134a. Also, COP values for R1234yf, R450A, and R1234ze(E) were lower than those obtained from R134a. Makhnatch et al. [20] energetically evaluated R-450A and R-513A in comparison with R-134a in an experimental system at higher condensation temperatures. While R-513A surpassed the COP of $\mathrm{R}-134 \mathrm{a}$ in $1.8 \%$, R-450A presented a decrease of $5.3 \%$. Daviran et al [21] concluded that the refrigerant-side overall heat transfer coefficient of HFO-1234yf was 18-21\% lower than that of HFC-134a, and the pressure drop was $24 \%$ and $20 \%$ smaller than HFC-134a during condensing and evaporating processes, respectively. Further, in a constant cooling capacity, the COP of HFO-1234yf was lower than HFC-134a by $1.3 \%-5 \%$, and in the second case, the COP of HFO-1234yf was about $18 \%$ higher than that of HFC-134a. Navarro-Esbrí et al. [22] studied R1234yf performance in a vapor compression system varying a wide range of condition, concluding that the cooling capacity and COP for R1234yf were about $9 \%$ and $19 \%$ lower than those obtained using R134a. Meng et. al [23] deduced that the capacities of R1234yf/R134a and R134a were similar in cooling and heating modes. The COP of R1234yf/R134a was lower than that of R134a by 4-9\% in cooling mode, whereas it was lower by $4-16 \%$ in heating mode. Lee and Jung [24] compared the performance of refrigeration systems using R1234yf and R134a as working fluid in the drop-in tests. The results of the experiment showed that the COP of R1234yf systems was $2.7 \%$ lower than that of R134a system. Zilio et al. [25] concluded that the R1234yf cooling capacity and COP in a MAC were considerably lower than those obtained with R134a, and they suggested some hardware modifications in order to reduce the difference between both refrigerants. Cho et al. [26] concluded that when R134a and R1234yf were compared, R1234yf systems without internal heat exchangers (IHX) experienced a decrease of approximately $7 \%$ and $4.5 \%$ in cooling capacity and COP.

The aim of this paper was to create a mathematical model that would enable the detailed description of thermodynamic processes within heat pump system using internal heat exchangers, as well as determine the parameter changes in any point of the cycle.

The research will compare the COP, the heating capacity and the compressor power consumption of the heat pump system with internal heat exchanger in a wide range of operating conditions of a monitored heat pump system using R134a and R1234yf refrigerants. The mathematical model of the heat pumps was steady-state with lumped parameters. The experimental validation of the model was carried out with 36 tests using R134a and R1234yf as working fluid.

\section{Design of the mathematical model for the heat pump system}

This concentrated parameter mathematical model takes into account all main components of the heat exchanger heat pump system. These are the evaporator and condenser which are shell and tube heat exchangers, the IHX which is a plate heat exchanger, the reciprocating compressor, and the capillary tubes.

The evaporator is divided into one zone, namely evaporation, the condenser is divided into two zones, namely superheating, two-phase zones. Lumped parameters are considered in each zone in the heat exchangers, and also in the compressor and in the expansion valve. The model disregards the following:

- Steady-state operating conditions.

- The superheated degree at the outlet of the evaporator and condenser are fixed as $0 \mathrm{~K}$.

- Pressure losses in the heat exchangers are neglected.

- Isenthalpic expansion process. 
The corresponding $\mathrm{p}-\mathrm{h}$ diagram of vapor compression cycle considered is presented in Fig. 1 [27].

\subsection{Evaporator}

Equations (1-3) detail the steady state energy balance in the evaporator:

- For the heat flux from the cooling water:

$$
q_{\text {eva }}=\dot{m}_{w} \cdot c_{p_{w}} \cdot\left(T_{\text {in }}-T_{\text {out }}\right) \text {. }
$$

- For the heat flux absorbed by the refrigerant:

$$
q_{\text {eva }}=\dot{m}_{r} \cdot\left(h_{1}-h_{4}\right) \text {. }
$$

- For the heat transfer between the cooled water and refrigerant is:

$$
q_{\text {eva }}=U \cdot A \cdot \Delta T_{l m} .
$$

\subsection{Condenser}

Equations (4-6) describe the steady state energy balance in the condenser:

- The heat flux absorbed by heated water is given in:

$$
q_{c o n}=\dot{m}_{w} \cdot c_{p_{w}} \cdot\left(T_{\text {in }}-T_{\text {out }}\right) .
$$

- The heat flux from the refrigerant is:

$$
q_{\text {con }}=\dot{m}_{r} \cdot\left(h_{2}-h_{3}\right) \text {. }
$$

- The heat transfer between the refrigerant and heated water is:

$$
q_{c o n}=U \cdot A \cdot \Delta T_{l m} .
$$

\subsection{Internal heat exchanger}

The heat transfer rate can be defined for three equations defined on the refrigerant - vapor, liquid-side and in the wall interface region. These are, respectively:

- Heat flux from the liquid phase of the refrigerant:

$$
q_{i h x}=h_{3}-h_{3^{\prime}}=\dot{m}_{r} \cdot c_{p_{\text {lqq }}} \cdot\left(T_{3}-T_{3^{\prime}}\right) .
$$

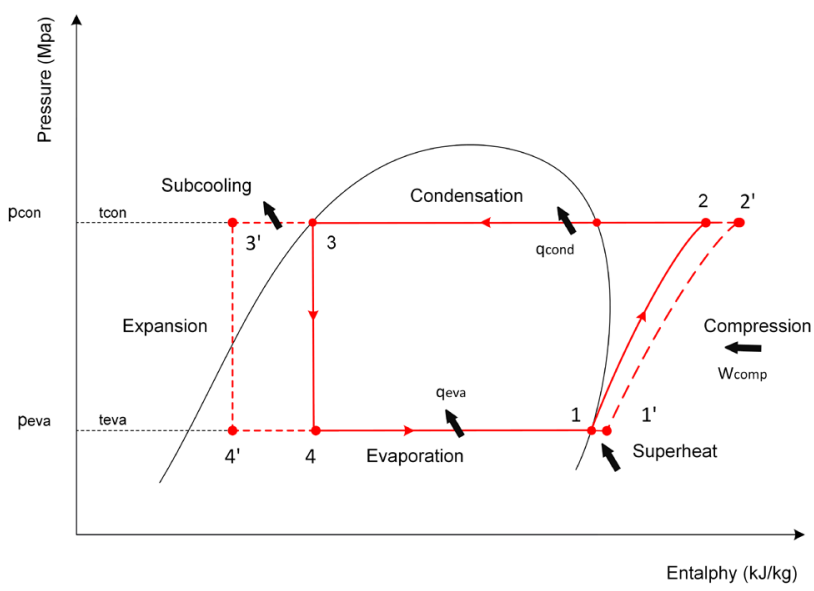

Fig. 1 p-h diagram of the heat pump cycle [27]
- Heat flux absorbed by the vapor phase of the refrigerant:

$$
q_{i h x}=h_{1}-h_{1}=\dot{m}_{r} \cdot c_{\text {pvap }} \cdot\left(T_{1},-T_{1}\right) .
$$

- The heat transfer between the vapor and liquid phase of the refrigerant:

$$
q_{i h x}=U \cdot A \cdot \Delta T_{l m} .
$$

\subsubsection{Auxiliary equations}

In addition to the afore-mentioned basic energy equations, several auxiliary equations are required in the simulation of the heat pump.

The intensity of the heat transfer between the vapor and liquid phase of the refrigerant or water and refrigerant were determined by the overall heat transfer coefficient:

$$
U=\frac{1}{\frac{1}{\alpha_{\text {vap }}}+\frac{\delta}{\lambda}+\frac{1}{\alpha_{l i q}}} .
$$

After neglecting the thermal resistance of the wall:

$U=\frac{\alpha_{v a p} \cdot \alpha_{l i q}}{\alpha_{v a p}+\alpha_{l i q}}$.

The literature lists numerous condensation heat transfer correlations for the various types of refrigerants and different conditions. In the model, the well-known Shah correlation [28] was applied:

$\alpha=\alpha_{f} \cdot\left(1+\frac{3.8}{Z}\right)$,

where:

$Z=\left(\frac{1-x}{x}\right)^{0.8} \cdot(p)^{0.4}$.

For single-phase heat transfer correlation determined with Eq. (17).

For the definition of the evaporation heat transfer correlation, the well-known Chan correlation [29] was used:

$\alpha_{t p}=F \cdot \alpha_{f}+S \cdot \alpha_{n b}$.

The two-phase correction multiplier for convective boiling:

$F=b \cdot \frac{C o^{c}}{X_{t t}^{d}}$.

The two-phase correction multiplier factor for bubble boiling:

$S=a \cdot(1-x)$.

For the single-phase heat transfer, it can be used DittusBoelter [30] correlation: 
$\mathrm{Nu}=0.023 \cdot \mathrm{Re}_{e}^{0.8} \cdot \operatorname{Pr}^{n}$

The logarithmic mean temperature differences in the heat exchangers can be calculated as seen here:

$\Delta T_{l m}=\frac{\Delta T_{\max }-\Delta T_{\min }}{\ln \frac{\Delta T_{\max }}{\Delta T_{\min }}}$.

\subsection{Expansion valve}

The same reference gives the capacity of TEV to be [31]:

$Q_{\text {tev }}=C_{o} \cdot \sqrt{\rho \cdot\left(t_{\text {con }}-t_{\text {eva }}\right)} \cdot\left[h_{\text {con }}-h_{\text {eva }}\right]$.

\subsection{Compressor}

The compressor power consumption is the enthalpy difference and is expressed as a function of the compressor efficiency:

$W=\dot{m}_{r} \cdot\left(h_{c o n}-h_{\text {eva }}\right) \cdot \frac{1}{\eta}$.

\section{Solution of the mathematical model of the heat pump system}

The solution of the algorithm makes it possible to understand and trace the logical structure of the solution of the formulated mathematical model since it gives the model its accuracy and applicability. The block diagram of the algorithm is shown in Fig. 2.

\section{Experimental procedure}

In the course of this research the author performed laboratory and service tests for the fully comprehensive computerized modeling of heat pump systems with IHX, to determine the primary and secondary water parameters, and the refrigeration thermodynamic parameters in the cycle. The specification of the heat pump with internal heat exchanger is presented in Table 1.

Measuring points were formed on the heat pump system, which is shown in Fig. 3. Various measuring instruments have been used to measure temperature, pressure, mass and volume flow as well as compressor power consumption.

The accuracy and uncertainty of the measuring equipment used in the experiments are summarized in Table 2.

Total number of measurements was 36.18 measurements were performed with R134a refrigerant and 18 measurements with R1234yf refrigerant. The measurement ranges are summarized in Table 3.

\section{Results and discussion}

The simplest way to verify the goodness of a mathematical model set up to describe the behavior of a heat

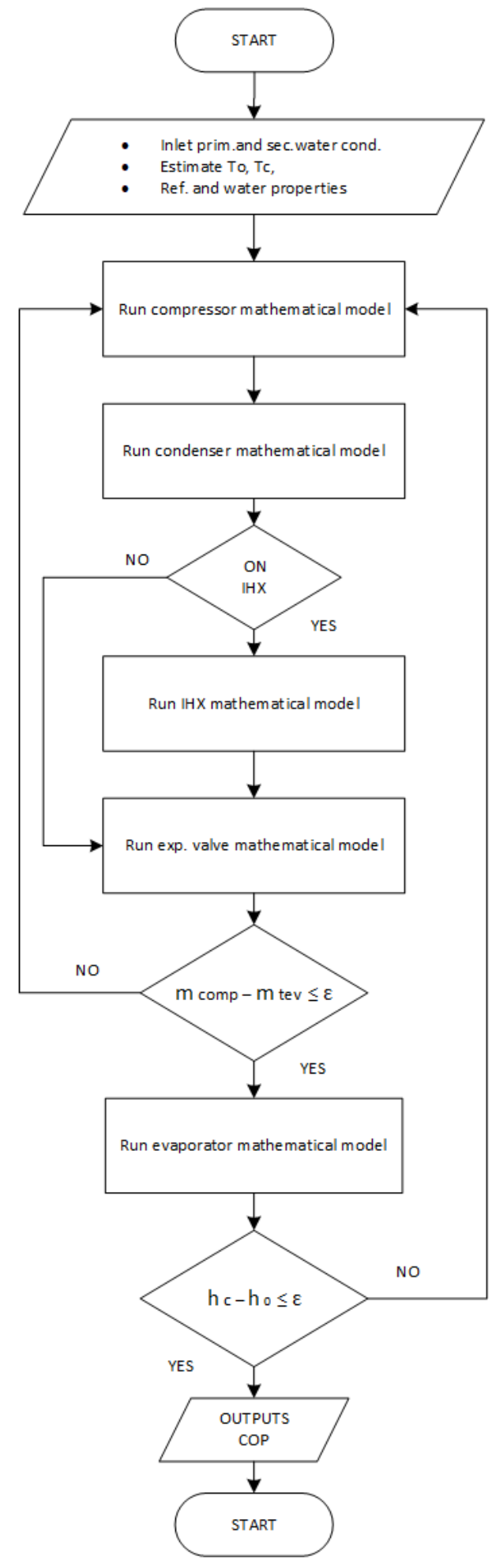

Fig. 2 Flowchart of the simulation program

pump system with an internal heat exchanger was to perform laboratory measurements and compare the obtained results with the results provided by the model, which are presented in Figs. 4-14.

The model error was determined by the difference between the real measured and predicted values of the energy parameters, according to Eq. (21): 
Table 1 Specifications of the main components of the heat pump system.

\begin{tabular}{lc}
\hline Name & Remarks \\
\hline Compressor & $\begin{array}{r}\text { Reciprocating compressor, CAJ4511Y 1hp Valve } \\
\text { Tecumseh Compressor R134a }\end{array}$ \\
\hline Shell and Tube Heat Exchanger. \\
Shell diameter: $32 \mathrm{~mm}$. \\
Tube diameter: $6 \mathrm{~mm}$. \\
Number of tubes: 5. \\
Evaporator length: $\mathrm{z}=3 \mathrm{~m}$ \\
\hline
\end{tabular}

Shell and Tube Heat Exchanger.

Shell diameter: $32 \mathrm{~mm}$.

Condensation Tube inner diameter: $6 \mathrm{~mm}$.

Number of tubes: 5 .

Condenser length: $3 \mathrm{~m}$

\begin{tabular}{lc}
\hline Expansion valve & Internally-equalized type \\
\hline $\begin{array}{l}\text { Internal heat } \\
\text { exchanger }\end{array}$ & Plate heat exchanger, SWEP no. 14314-010 \\
\hline
\end{tabular}

$H=\frac{\left|V_{\exp }-V_{\text {pred }}\right|}{V_{\text {exp }}}$.

In the current case, both refrigerants flow through in a tube bundle of the heat exchangers, while the primary and secondary fluid flows in the shell across the bundle. The evaporator was always operated with constant inlet cooling water temperatures $T_{c w}=13^{\circ} \mathrm{C}$, while the outlet heated water temperatures of the condenser were $T_{h w}=35^{\circ} \mathrm{C}$. The mass flow rate in the shell side of the evaporator and condenser were $\dot{m}_{w}=0.07 \frac{\mathrm{kg}}{\mathrm{s}}$.

The temperature profiles of the primary and secondary fluid at the outlet in the shell side of the evaporator and the condenser are shown in Figs. 4 and 5.

In Fig. 4, the maximum difference between the measured and predicted values for the temperature profile of the cooling water flow in the shell side of evaporator is $0.46{ }^{\circ} \mathrm{C}$, while Fig. 5 shows the deviation of the heated water flow in the shell side of condenser, which is $0.58^{\circ} \mathrm{C}$.

Figs. 6 and 7 show the difference between the measured and calculated values of the vapor phase refrigerant temperature profiles inlet and outlet of the compressor for refrigerants R134a and R1234yf. At the compressor inlet the discrepancy is a prediction error of $0.44{ }^{\circ} \mathrm{C}$, while at the compressor outlet, it is $0.57^{\circ} \mathrm{C}$.

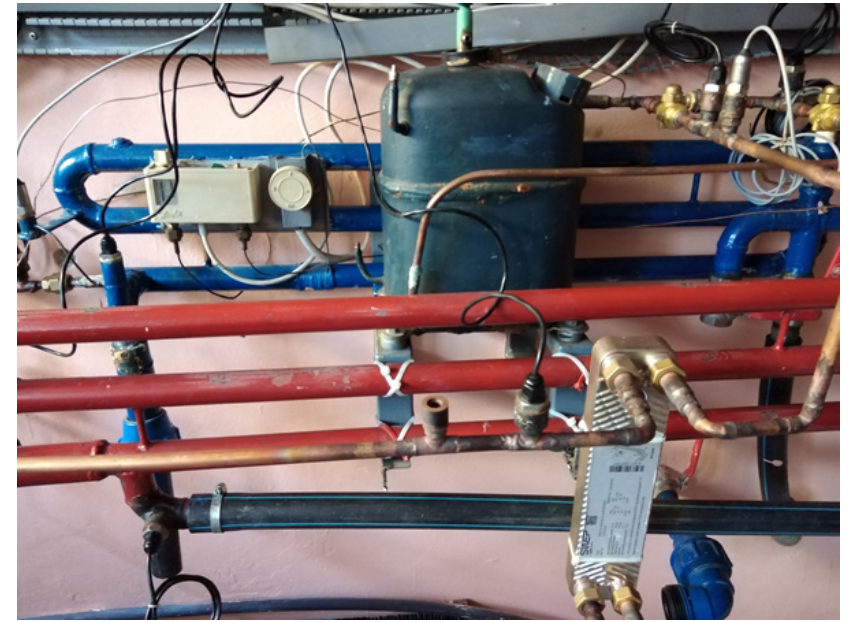

a)

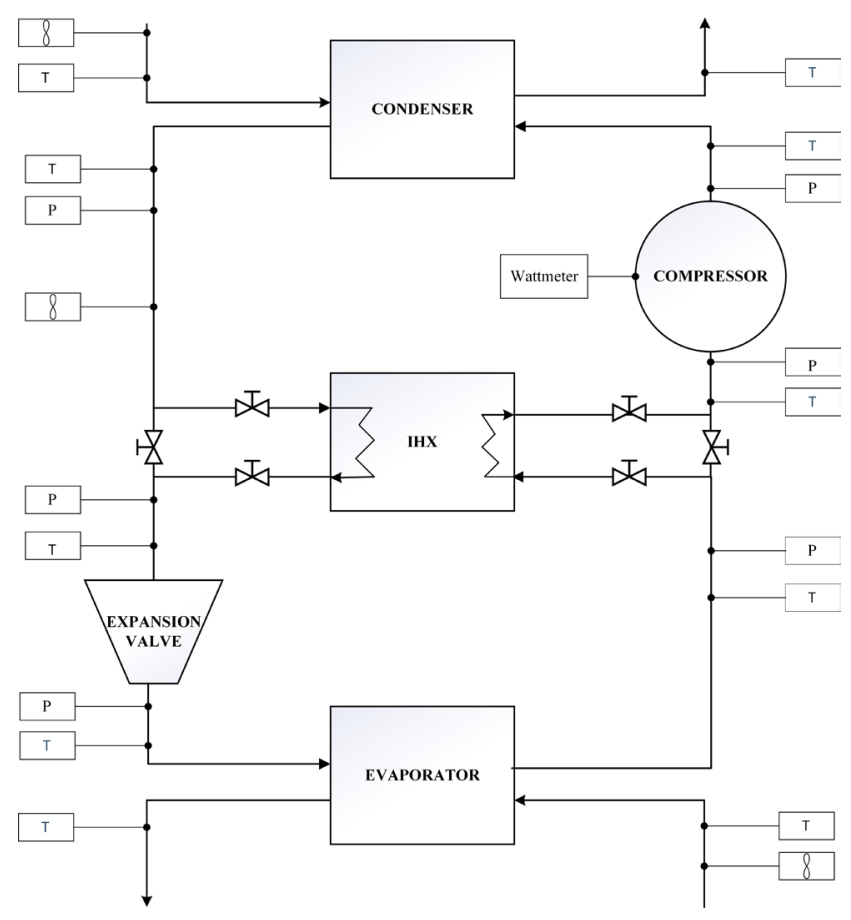

b)

Fig. 3 a) Photo and b) schematic diagram of the experimental setup

Table 2 Measured parameters and equipment uncertainty.

\begin{tabular}{|c|c|c|}
\hline Measured parameters & Sensor & Uncertainty \\
\hline Temperatures & $\begin{array}{l}\text { K-type thermocouples } \\
\text { DS18B20 90807A }\end{array}$ & $\pm 0.2 \mathrm{~K}$ \\
\hline Pressures & $\begin{array}{l}\text { Transducers TD220030 } \\
\text { ELIWELL EWPA } 030\end{array}$ & $\pm 1 \%$ \\
\hline Flow meters & $\begin{array}{l}\text { Coriolis mass flow meter, and } \\
\text { water flow sensors turbine } \\
\text { flowmeters }\end{array}$ & $\pm 0.2 \%$ \\
\hline $\begin{array}{l}\text { Compressor } \\
\text { power consumption }\end{array}$ & Digital watt meter & $\pm 0.15 \%$ \\
\hline
\end{tabular}


Table 3 Range of operating condition in the experimental tests.

\begin{tabular}{lc}
\hline Controlled parameters & Range values \\
\hline Condensing temperature $\left(T_{c o n}\right)$ & $41-62{ }^{\circ} \mathrm{C}$ \\
Evaporating temperature $\left(T_{\text {eva }}\right)$ & $3-6{ }^{\circ} \mathrm{C}$ \\
Compressor power consumption $(\mathrm{W})$ & $600-1400 \mathrm{~W}$ \\
\hline
\end{tabular}

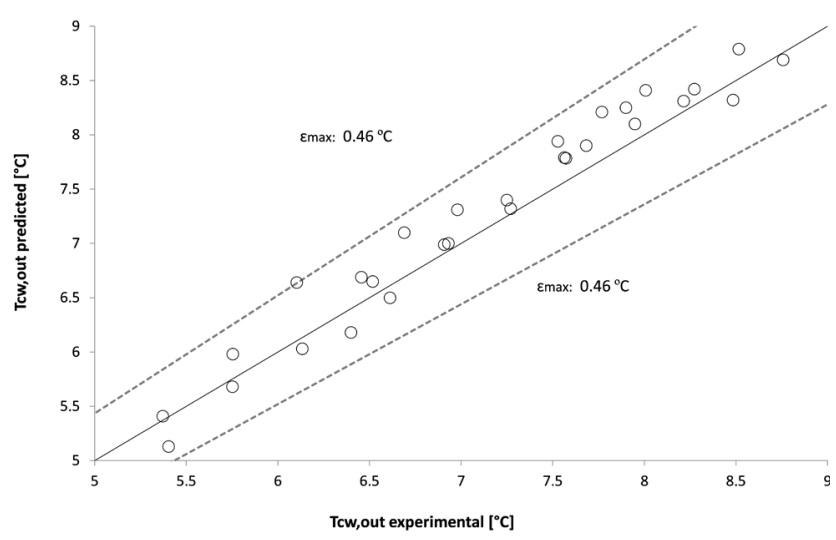

Fig. 4 Prediction of the water temperature in the shell side evaporator

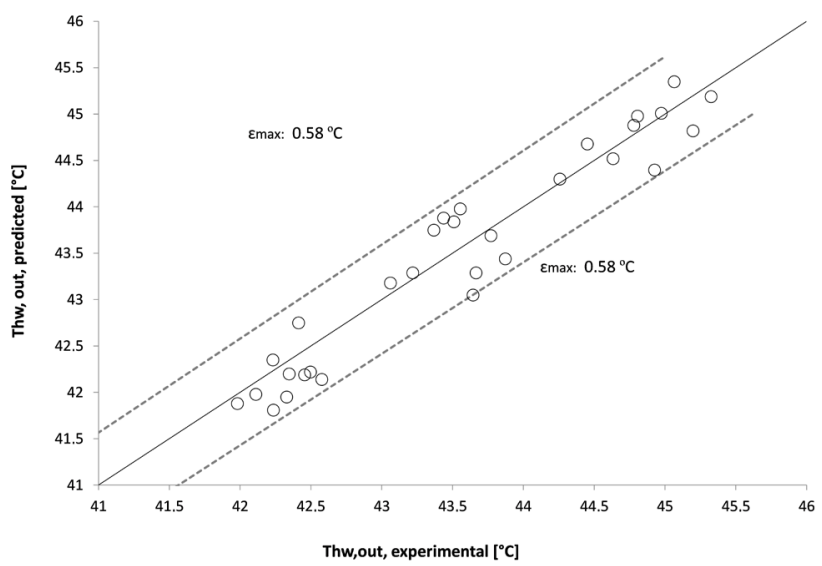

Fig. 5 Prediction of the water temperature in the shell side condenser

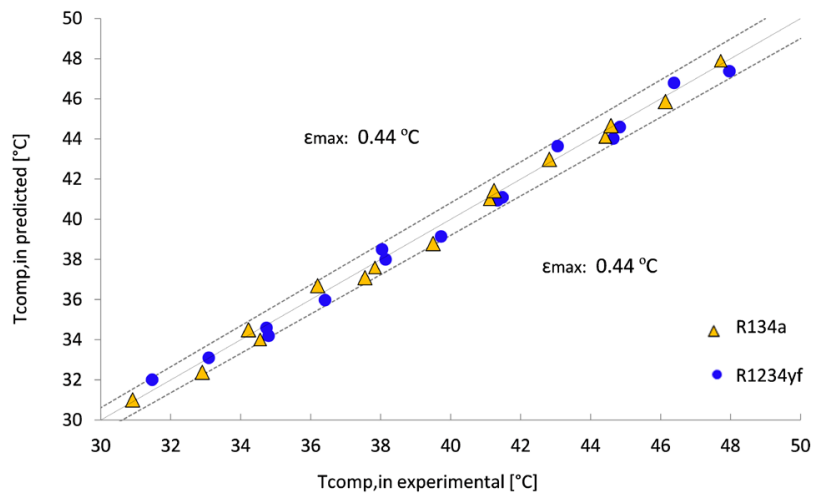

Fig. 6 Prediction of the temperature at the compressor inlet

Fig. 8 shows the difference between the temperature values obtained from the model and the measured values for the two refrigerants. The relative error prediction for the internal heat exchanger outlet temperature is about $0.39^{\circ} \mathrm{C}$, when the refrigerant is in the liquid phase.

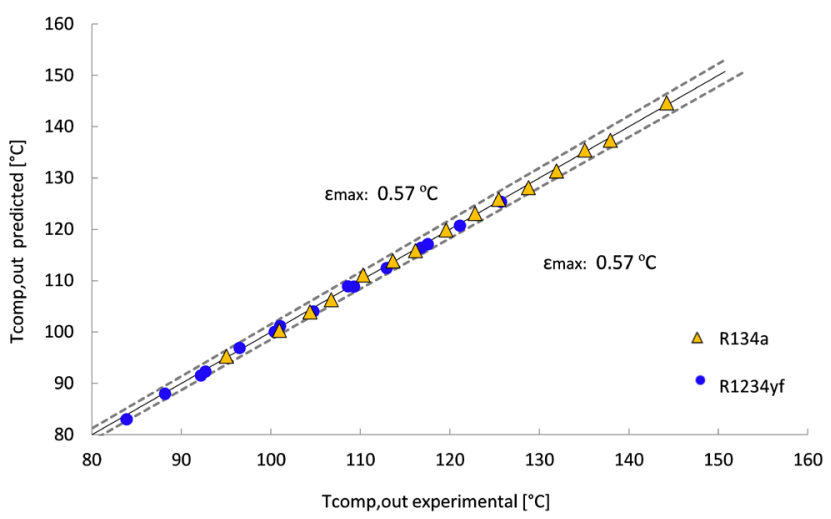

Fig. 7 Prediction of the temperature at the compressor outlet

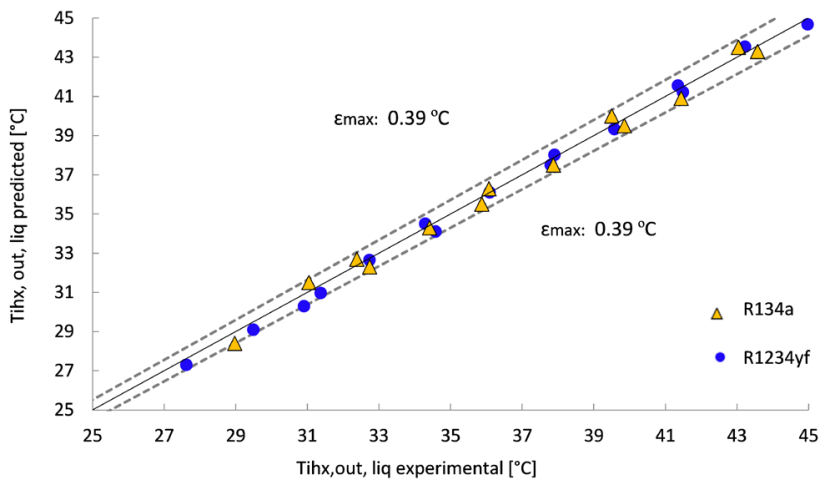

Fig. 8 Prediction of the temperature at the internal heat exchanger outlet

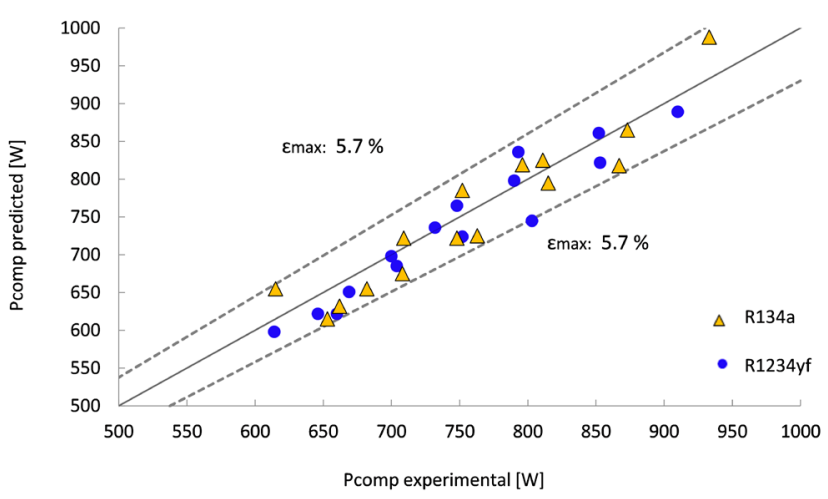

Fig. 9 Prediction of compressor power consumption

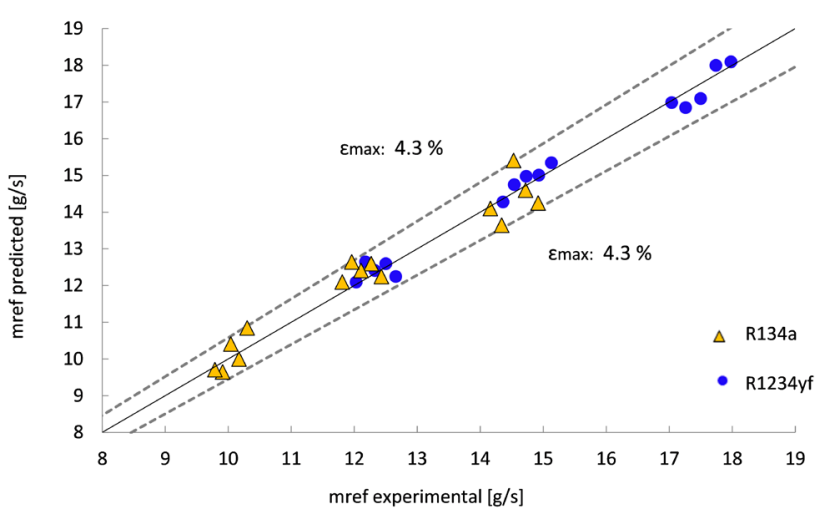

Fig. 10 Prediction of the refrigerant mass flow rate 


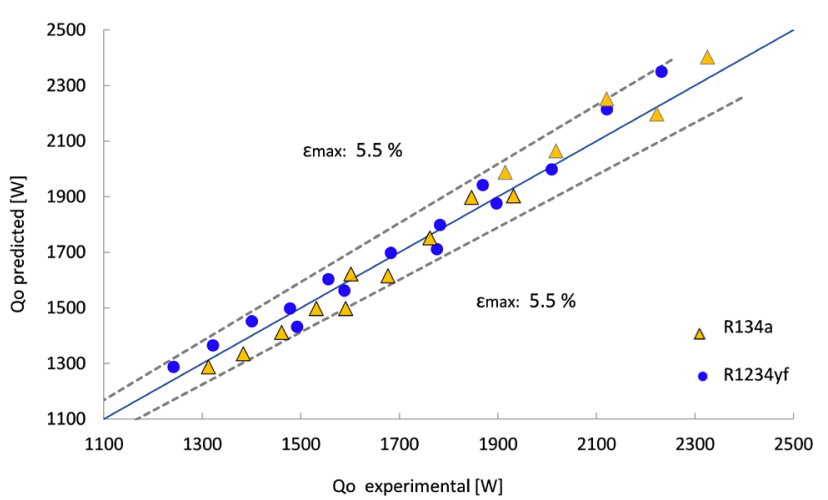

Fig. 11 Prediction of the cooling capacity

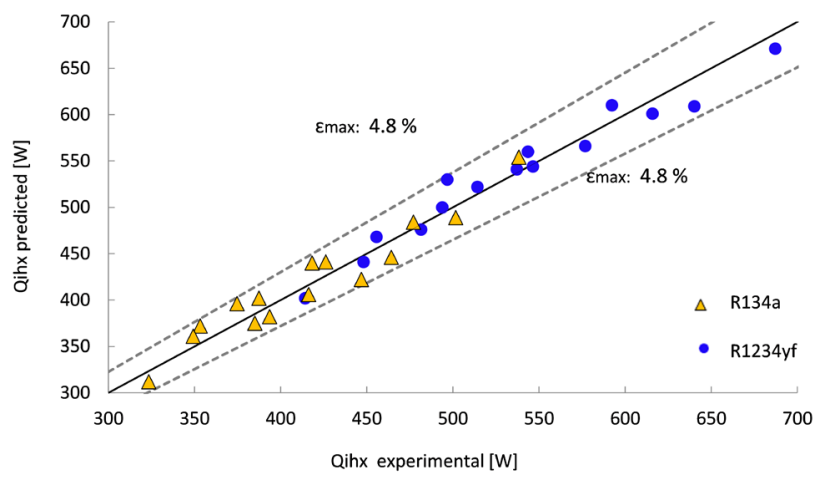

Fig. 12 Prediction of the heat transfer rate in the internal heat exchanger

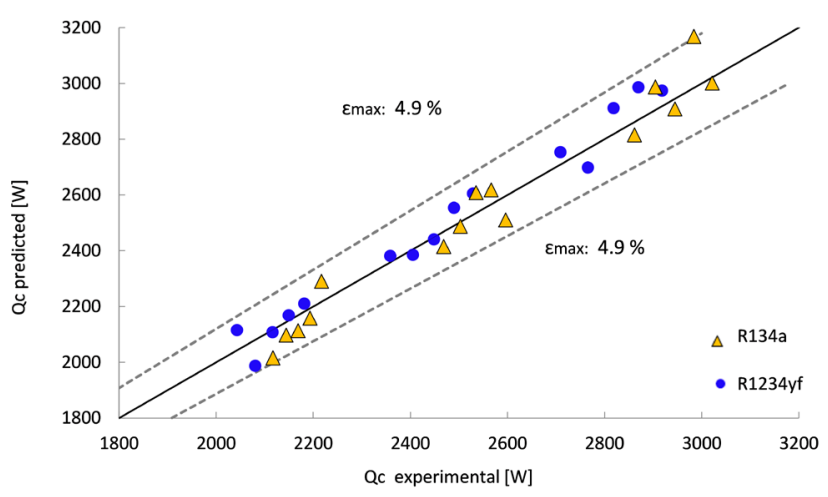

Fig. 13 Prediction of condenser capacity

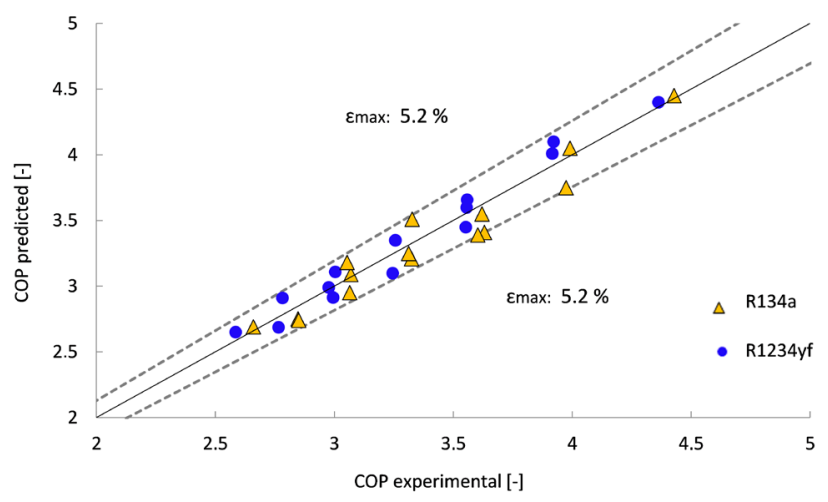

Fig. 14 Prediction of the coefficient of performance COP
As shown in Fig. 9, the maximum deviation of the compressor power consumption values obtained from the model from the measured values is $5.7 \%$ for the R1234yf and R134a refrigerants.

The comparison between the measured mass flow rate values with the model values is given in Fig. 10. The predicted values are within an error of $4.3 \%$.

Fig. 11 shows that the maximum deviation of the cooling capacity values provided by the model from the measured values is $5.2 \%$ for R134a and R1234yf refrigerants.

Figs. 12 and 13 show the difference between predicted and measured values of the heat transfer rate in the internal heat exchangers and the condenser capacity. The predicted values are within an error of $4.8 \%$ and about $4.9 \%$, respectively.

Fig. 14 shows the difference between the model and the experimental results for the COP values using both refrigerants. It can be seen that the maximum relative difference was $5.4 \%$. The mathematical model error is acceptable, similar to other research results mentioned in literature [7, 10, 17]. Figs. 15-17 compare the various energy performance values of the heat pump system with internal heat exchanger in a wide range of operating conditions using the R134a and R1234yf refrigerants.

Fig. 15 shows the variation of compressor power consumption at different condensation temperatures from $50{ }^{\circ} \mathrm{C}$ to $80{ }^{\circ} \mathrm{C}$ and evaporation temperatures from $-10{ }^{\circ} \mathrm{C}$ to $10{ }^{\circ} \mathrm{C}$ using R134a and R1234yf. For R1234yf the values of compressor power consumption are very similar to those for R134a at low condensation temperature $50^{\circ} \mathrm{C}$. When the condensation temperature is higher, $80^{\circ} \mathrm{C}$ and the evaporation temperature rises to $10^{\circ} \mathrm{C}$, the difference is $3.51 \%$. In fact, the values determined for $\mathrm{R} 134 \mathrm{a}$ are higher than those determined for R1234yf.

Fig. 16 shows the variation of heating capacity at different condensation temperatures from $50^{\circ} \mathrm{C}$ to $80^{\circ} \mathrm{C}$ and evaporation temperatures from $-10{ }^{\circ} \mathrm{C}$ to $10{ }^{\circ} \mathrm{C}$ using R134a and R1234yf. For R1234yf, the heating capacity values are smaller than those obtained for R134a under the above-mentioned conditions. In smaller evaporation temperatures $-10^{\circ} \mathrm{C}$ and condensation temperatures $50^{\circ} \mathrm{C}$, the difference between heating capacities of R1234yf and R134a is very similar at $0.63 \%$. When the evaporation temperature rises from $-10{ }^{\circ} \mathrm{C}$ to $10{ }^{\circ} \mathrm{C}$, the difference is $3.74 \%$ in the case of R134a. When higher condensation temperature $80{ }^{\circ} \mathrm{C}$ is considered, the difference between heating capacities of $\mathrm{R} 1234 \mathrm{yf}$ and R134a is increased. The difference between both refrigerants increases between $4.18 \%$ and $7.54 \%$ when 


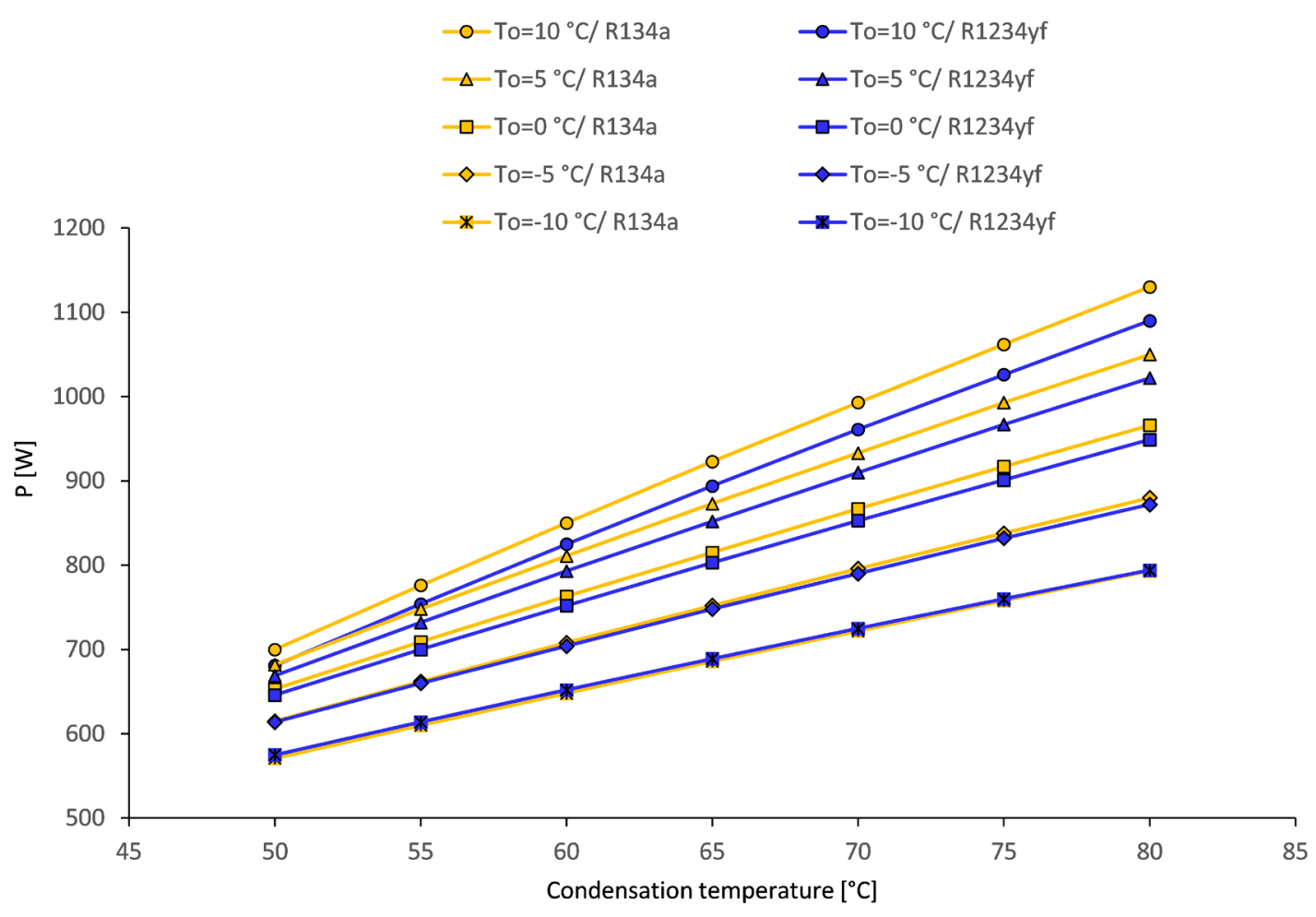

Fig. 15 Compressor power consumption versus condensation temperature

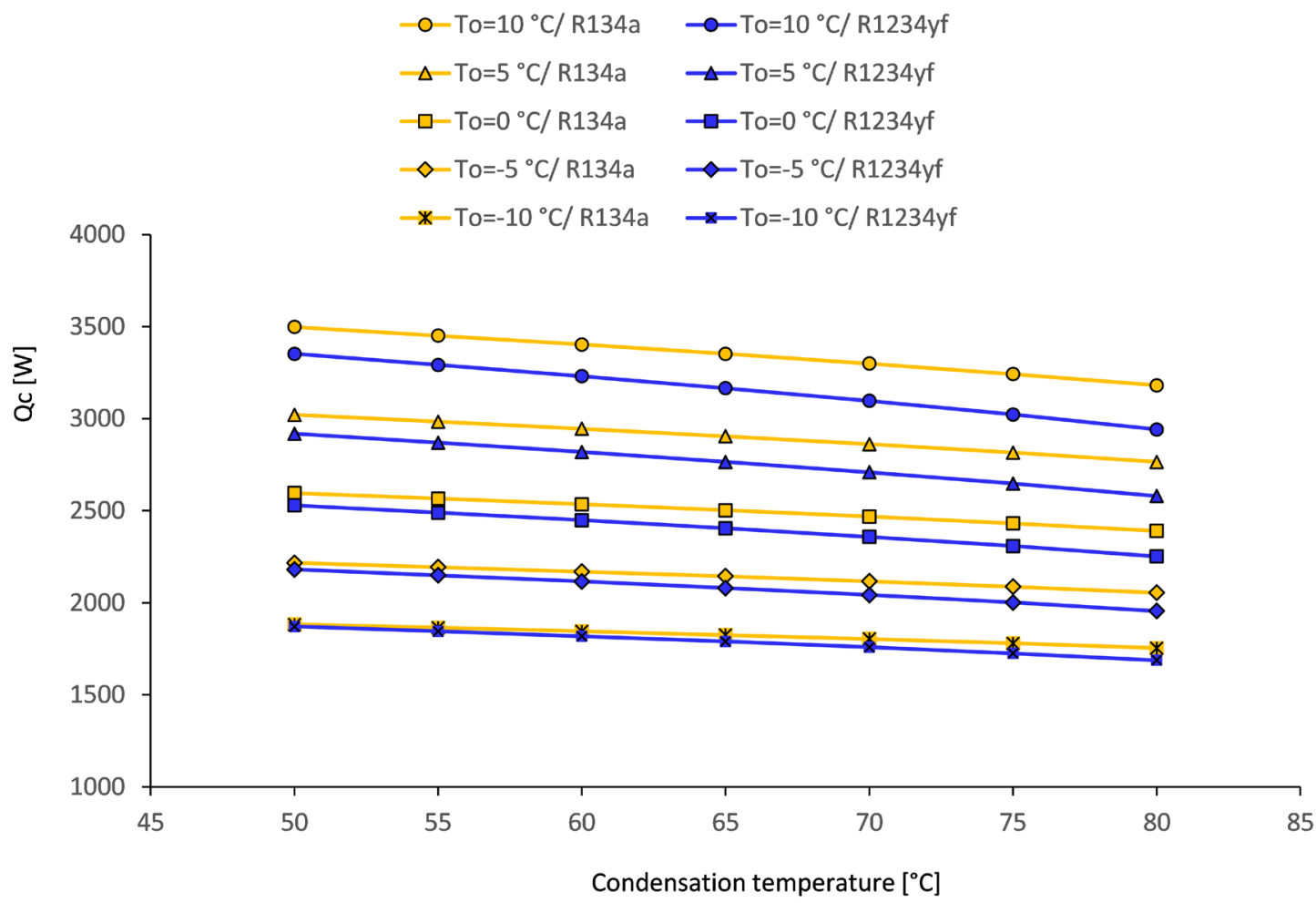

Fig. 16 Heating capacity versus condensation temperature

evaporation temperatures change from $-10{ }^{\circ} \mathrm{C}$ to $10^{\circ} \mathrm{C}$, i.e., in all cases R134a provides the greater values.
Fig. 17 shows the variation of COP at different condensation temperatures from $50{ }^{\circ} \mathrm{C}$ to $80{ }^{\circ} \mathrm{C}$ and evaporation 


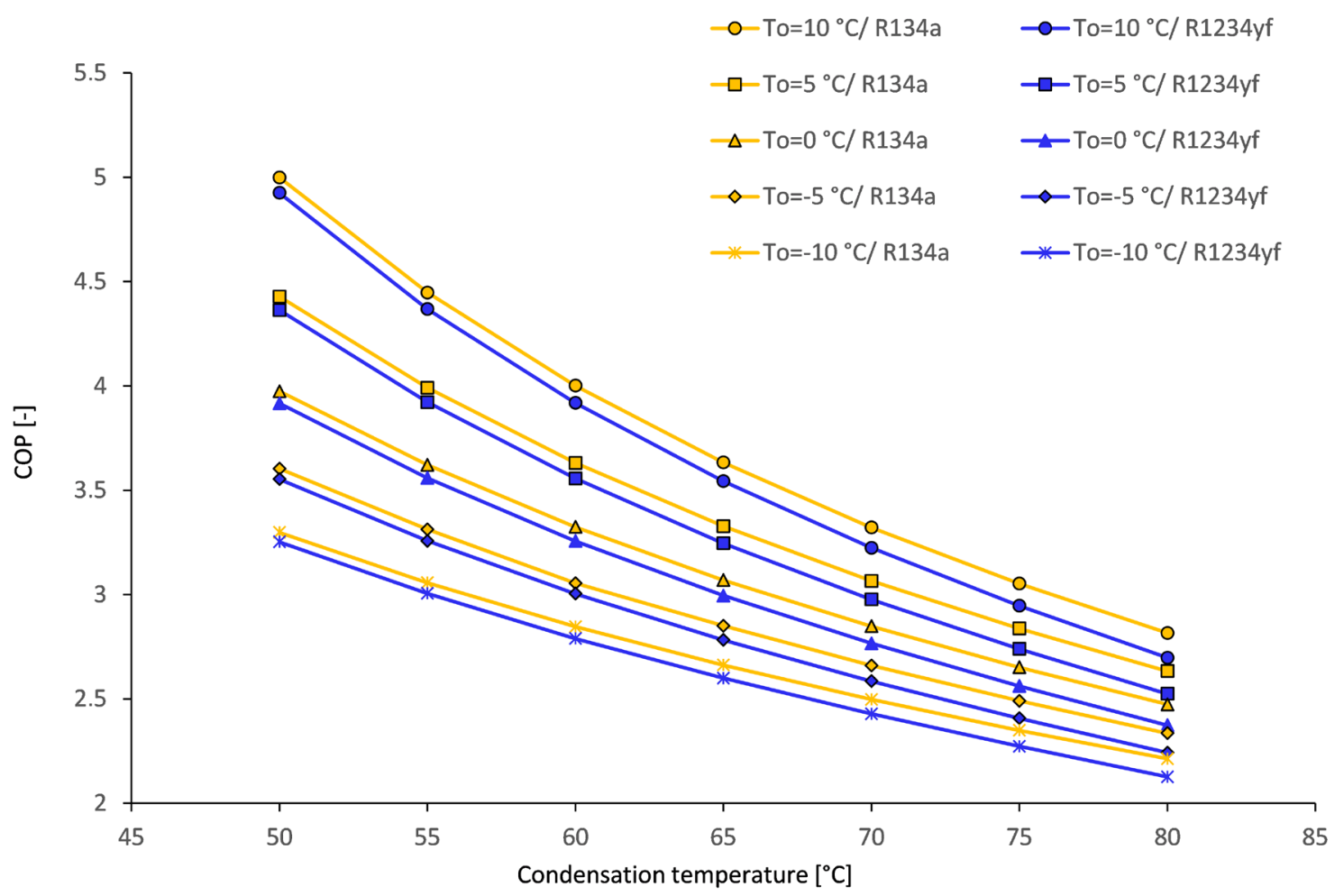

Fig. $17 \mathrm{COP}$ versus condensation temperature

temperatures from $-10{ }^{\circ} \mathrm{C}$ to $10{ }^{\circ} \mathrm{C}$ using $\mathrm{R} 134 \mathrm{a}$ and R1234yf. For R1234yf the COP values are smaller than those for R134a as measured in the above-mentioned conditions. In smaller evaporation $-10{ }^{\circ} \mathrm{C}$ and condensation temperatures $50{ }^{\circ} \mathrm{C}$, the difference between COP values of $\mathrm{R} 1234 \mathrm{yf}$ and $\mathrm{R} 134 \mathrm{a}$ is $1.38 \%$, with R134a being greater. At condensation temperature $50{ }^{\circ} \mathrm{C}$, when the evaporation temperature rises from $-10{ }^{\circ} \mathrm{C}$ to $10{ }^{\circ} \mathrm{C}$, the difference in COP values is higher, at $3.93 \%$ where the higher values stem from R134a. When higher condensation temperatures $80^{\circ} \mathrm{C}$ are considered, the difference between COP values of R1234yf and R134a is increased. The difference between both refrigerants increases between $1.48 \%$ and $4.22 \%$ when evaporation temperatures change from $-10{ }^{\circ} \mathrm{C}$ to $10{ }^{\circ} \mathrm{C}$, again the higher value is that for $\mathrm{R} 134 \mathrm{a}$.

\section{Conclusions}

This paper presents a steady-state model for a vapor compression heat pump with internal heat exchanger. During the research, the author compared the proposed and experimental results obtained in the test bench using R1234yf and $\mathrm{R} 134 \mathrm{a}$, for the main energy performance parameters: cooling and heating capacity, heat transfer rate in the IHX, compressor power consumption, and COP. Other variables of interest, such as refrigerant mass flow rate, temperature of refrigerant in the main points of the cycle and primary and secondary water temperature were also included. The results are summed up in Figs. 4-14. A total of 36 experimental tests were conducted for the model validation using a wide range of operating conditions, which allowed for thoroughly checking the model for robustness. Furthermore, the energy performance of the heat pumps was compared using both refrigerants in function of the evaporation temperature between $-10{ }^{\circ} \mathrm{C}$ and $10{ }^{\circ} \mathrm{C}$, and the condensation temperature between $50{ }^{\circ} \mathrm{C}$ and $80^{\circ} \mathrm{C}$. The compressor power consumption for R1234yf is similar than that obtained for R134a when the evaporation $-10{ }^{\circ} \mathrm{C}$ and condensation temperature $50{ }^{\circ} \mathrm{C}$ are low, as summarized in Fig 15. The difference between both refrigerants decreases by between $2.7 \%$ and $3.53 \%$ when the condensation temperatures was $80{ }^{\circ} \mathrm{C}$, the greater value is that of $\mathrm{R} 134 \mathrm{a}$.

The heating capacity for R1234yf is between $0.63 \%$ and $7.54 \%$ lower than for R134a in the tested range, which is presented in Fig. 16, whereas Fig. 17 illustrates the COP difference obtained using R1234yf, which is between $1.48 \%$ and $4.22 \%$ lower than that obtained for R134a. The tests highlight that in conditions when the condensation temperature rises, the COP difference will also increase. Further research in the topic could be conducted in the field of investigating energetics parameters of the heat pump systems, both with or without the use of IHX. 


\section{References}

[1] Innovációs és Technológiai Minisztérium "Nemzeti Energia- és Klímaterv" (Hungary's National Energy and Climate Plan), [pdf] Ministry of Innovation and Technology, Hungary, Available at: https://ec.europa.eu/energy/sites/ener/files/documents/hu_final_ necp_main_hu.pdf [Accessed: 19 April 2021] (in Hungarian)

[2] Sánta, R., Garbai, L., Fürstner, I. "Optimization of heat pump system", Energy, 89, pp. 45-54, 2015.

https://doi.org/10.1016/j.energy.2015.07.042

[3] Sánta, R., Garbai, L., Fürstner, I. "Numerical investigation of the heat pump system", Journal of Thermal Analysis and Calorimetry, 130(2), pp. 1133-1144, 2017.

https://doi.org/10.1007/s10973-017-6489-8

[4] Ma, Y., Liu, Z., Tian, H. "A review of transcritical carbon dioxide heat pump and refrigeration cycles", Energy, 55, pp. 156-172, 2013. https://doi.org/10.1016/j.energy.2013.03.030

[5] Cao, F., Ye, Z., Wang, Y. "Experimental investigation on the influence of internal heat exchanger in a transcritical $\mathrm{CO}_{2}$ heat pump water heater", Applied Thermal Engineering, 168, Article number: $114855,2020$.

https://doi.org/10.1016/j.applthermaleng.2019.114855

[6] Belman-Flores, J. M., Rangel-Hernández, V. H., Usón, S., RubioMaya, C. "Energy and exergy analysis of R1234yf as drop-in replacement for R134a in a domestic refrigeration system", Energy, 132, pp. 116-125, 2017.

https://doi.org/10.1016/j.energy.2017.05.074

[7] Mota-Babiloni, A., Navarro-Esbrí, J., Barragán-Cervera, Á., Molés, F., Peris, B. "Drop-in analysis of an internal heat exchanger in a vapour compression system using R1234ze(E) and R450A as alternatives for R134a", Energy, 90(2), pp. 1636-1644, 2015. https://doi.org/10.1016/j.energy.2015.06.133

[8] Wang, D., Yu, B., Shi, J., Chen, J. "Experimental and Theoretical Study on the Cooling Performance of a $\mathrm{CO}_{2}$ Mobile Air Conditioning System", Energies, 11(8), Article number: 1927, 2018. https://doi.org/10.3390/en11081927

[9] Cao, F., Wang, Y., Ye, Z. "Theoretical analysis of internal heat exchanger in transcritical $\mathrm{CO}_{2}$ heat pump systems and its experimental verification", International Journal of Refrigeration, 106, pp. 506-516, 2019.

https://doi.org/10.1016/j.ijrefrig.2019.05.022

[10] Navarro-Esbrí, J., Molés, F., Barragán-Cervera, Á. "Experimental analysis of the internal heat exchanger influence on a vapour compression system performance working with R1234yf as a drop-in replacement for R134a", Applied Thermal Engineering, 59(1-2), pp. 153-161, 2013.

https://doi.org/10.1016/j.applthermaleng.2013.05.028

[11] Devecioğlu, A. G., Oruç, V. "Improvement on the energy performance of a refrigeration system adapting a plate-type heat exchanger and low-GWP refrigerants as alternatives to R134a", Energy, 155, pp. 105-116, 2018.

https://doi.org/10.1016/j.energy.2018.05.032

[12] Yang, M., Zhang, H., Meng, Z., Qin, Y. "Experimental study on R1234yf/R134a mixture (R513A) as R134a replacement in a domestic refrigerator", Applied Thermal Engineering, 146, pp. $540-547,2019$.

https://doi.org/10.1016/j.applthermaleng.2018.09.122
[13] Mota-Babiloni, A., Belman-Flores, J. M., Makhnatch, P., NavarroEsbrí, J., Barroso-Maldonado, J. M. "Experimental exergy analysis of R513A to replace R134a in a small capacity refrigeration system", Energy, 162, pp. 99-110, 2018.

https://doi.org/10.1016/j.energy.2018.08.028

[14] Pérez-García, V., Mota-Babiloni, A., Navarro-Esbrí, J. "Influence of operational modes of the internal heat exchanger in an experimental installation using R-450A and R-513A as replacement alternatives for R-134a", Energy, 189, Article number: 116348, 2019. https://doi.org/10.1016/j.energy.2019.116348

[15] Mota-Babiloni, A., Navarro-Esbrí, J., Barragán-Cervera, Á., Molés, F., Peris, B. "Experimental study of an R1234ze(E)/R134a mixture (R450A) as R134a replacement", International Journal of Refrigeration, 51, pp. 52-58, 2015. https://doi.org/10.1016/j.ijrefrig.2014.12.010

[16] Mota-Babiloni, A., Navarro-Esbrí, J., Pascual-Miralles, V., BarragánCervera, Á., Maiorino, A. "Experimental influence of an internal heat exchanger (IHX) using R513A and R134a in vapor compression system", Applied Thermal Engineering, 147, pp. 482-491, 2019. https://doi.org/10.1016/j.applthermaleng.2018.10.092

[17] Wantha, C. "Analysis of heat transfer characteristics of tube-intube internal heat exchangers for HFO-1234yf and HFC-134a refrigeration systems", Applied Thermal Engineering, 157, Article number: 113747, 2019. https://doi.org/10.1016/j.applthermaleng.2019.113747

[18] Belman-Flores, J. M., Rodríguez-Muñoz, A. P., Pérez-Reguera, C. G., Mota-Babiloni, A. "Experimental study of R1234yf as a drop-in replacement for R134a in a domestic refrigerator", International Journal of Refrigeration, 81, pp. 1-11, 2017. https://doi.org/10.1016/j.ijrefrig.2017.05.003

[19] Mendoza-Miranda, J. M., Mota-Babiloni, A., Ramírez-Minguela, J. J., Muñoz-Carpio, V. D., Carrera-Rodríguez, M., Navarro-Esbrí, J., Salazar-Hernández, C. "Comparative evaluation of R1234yf, $\mathrm{R} 1234 \mathrm{ze}(\mathrm{E})$ and $\mathrm{R} 450 \mathrm{~A}$ as alternatives to R134a in a variable speed reciprocating compressor", Energy, 114, pp. 753-766, 2016. https://doi.org/10.1016/j.energy.2016.08.050

[20] Makhnatch, P., Mota-Babiloni, A., López-Belchí, A., Khodabandeh, R. "R450A and R513A as lower GWP mixtures for high ambient temperature countries: Experimental comparison with R134a, Energy, 166, pp. 223-235, 2019. https://doi.org/10.1016/j.energy.2018.09.001

[21] Daviran, S., Kasaeian, A., Golzari, S., Mahian, O., Nasirivatan, S., Wongwises, S. "A comparative study on the performance of HFO1234yf and HFC-134a as an alternative in automotive air conditioning systems", Applied Thermal Engineering, 110, pp. 1091-1100, 2017. https://doi.org/10.1016/j.applthermaleng.2016.09.034

[22] Navarro-Esbrí, J., Mendoza-Miranda, J. M., Mota-Babiloni, A., Barragán-Cervera, A., Belman-Flores, J. M. "Experimental analysis of R1234yf as a drop-in replacement for R134a in a vapor compression system", International Journal of Refrigeration, 36(3), pp. 870-880, 2013. https://doi.org/10.1016/j.ijrefrig.2012.12.014 
[23] Meng, Z., Zhang, H., Lei, M., Qin, Y., Qiu, J. "Performance of low GWP R1234yf/R134a mixture as a replacement for R134a in automotive air conditioning systems", International Journal of Heat and Mass Transfer, 116, pp. 362-370, 2018.

https://doi.org/10.1016/j.ijheatmasstransfer.2017.09.049

[24] Lee, Y., Jung, D. "A brief performance comparison of R1234yf and R134a in a bench tester for automobile applications", Applied Thermal Engineering, 35, pp. 240-242, 2012. https://doi.org/10.1016/j.applthermaleng.2011.09.004

[25] Zilio, C., Brown, J. S., Schiochet, G., Cavallini, A. "The refrigerant R1234yf in air conditioning systems", Energy, 36(10), pp. 6110-6120, 2011.

https://doi.org/10.1016/j.energy.2011.08.002

[26] Cho, H., Lee, H., Park, C. "Performance characteristics of an automobile air conditioning system with internal heat exchanger using refrigerant R1234yf", Applied Thermal Engineering, 61(2), pp. 563-569, 2013.

https://doi.org/10.1016/j.applthermaleng.2013.08.030

[27] Duarte, M. V., Pires, L. C., Silva, P. D., Gaspar, P. D. "Experimental comparison between R409A and R437A performance in a heat pump unit", Open Engineering, 7(1), pp. 77-90, 2017. https://doi.org/10.1515/eng-2017-0011
[28] Shah, M. M. "A general correlation for heat transfer during film condensation inside pipes", International Journal of Heat and Mass Transfer, 22(4), pp. 547-556, 1979. https://doi.org/10.1016/0017-9310(79)90058-9

[29] Mahmoud, M. M., Karayiannis, T. G. "Heat transfer correlation for flow boiling in small to micro tubes", International Journal of Heat and Mass Transfer, 66, pp. 553-574, 2013. https://doi.org/10.1016/j.ijheatmasstransfer.2013.07.042

[30] Dittus, F. W., Boelter, L. M. K. "Heat transfer in automobile radiators of the tubular type", International Communications in Heat and Mass Transfer, 12(1), pp. 3-22, 1985. https://doi.org/10.1016/0735-1933(85)90003-X

[31] Eames, I. W., Milazzo, A., Maidment, G. G. "Modelling thermostatic expansion valves", International Journal of Refrigeration, 38, pp. 189-197, 2014.

https://doi.org/10.1016/j.ijrefrig.2013.06.010 